rates of viral spread differently. Longini's group assumed it takes four days for an infected individual to be able to infect others, a figure used in previous models. But Ferguson reanalysed historical data and came up with a figure of just 2.6 days.

Longini's simulation also models 500,000 individuals laid out on a regular grid, whereas Ferguson's maps the population densities of all of Thailand's 85 million people, albeit in less detail. The larger scale makes it easier to take account of clusters arising outside the initial outbreak area.

\section{Too slow}

Both groups agree that, for a containment strategy to have any hope of working, it must be in place within a few weeks at most of the first people being infected with a virus capable of sustained human-to-human transmission.

If such a virus arose today, that is unlikely to happen. Surveillance systems in southeast Asia are poor; recent cases have taken weeks to detect and diagnose. Whereas Cambodia has typically reported cases to the World Health Organization (WHO) within about a week, Vietnam has often reported cases after several weeks, and in some cases months.

Marc Lipsitch, an epidemiologist at Harvard University, says the papers leave him concerned that too little is being done to plan containment strategies. "We are simply not moving fast enough," he says.

For example, the WHO currently has just 120,000 courses of antivirals in its stockpile, although it is in discussions to get more. "I think the take-home message is that the current stockpile is very unlikely to be adequate to stop anything," says Lipsitch.

What's needed, says Ben Schwartz of the National Immunization Program at the Centers for Disease Control and Prevention in Atlanta, are international agreements on how to investigate and report clusters; training and resources to strengthen surveillance; and measures to ensure that the WHO has enough antiviral drugs. The countries where a pandemic is most likely to emerge need detailed plans and drills, he adds.

The $\$ 25$ million spent by the United States last year in boosting surveillance in Asia is inadequate, says Schwartz. He points out that the country spent more than $\$ 800$ million on anthrax vaccines, "against a pathogen that has killed only a handful of Americans and whose bioterrorist potential is unproven".

Declan Butler

1. Ferguson, N. M. et al. Nature doi:10.1038/nature04017 (2005).

2. Longini, I. M. Jr et al. Science doi:10.1126/science.1115717 (2005)

\title{
US energy bill pushes research but fails to cut consumption
}

\section{WASHINGTON DC}

The US Congress slapped an energy bill, four years in the making, on President George W. Bush's desk last week.

The United States uses vastly more energy than any other country on the planet, and the bill was initially seen as a chance to set out a clear strategy for the country in terms of energy efficiency.

But in the end, critics say, the 1,700-page Energy Policy Act is more of a compromise than a strategy. It has been shorn of many of its controversial provisions, and won't do much to make the country's energy use more environmentally friendly, at least in the short term. But its various tax breaks and incentives may change the landscape of energy science.

In the past few months, sections of the bill protecting manufacturers of the water-contaminating petrol additive MTBE and opening the Arctic National Wildlife Refuge to oil drilling were scrapped so that Congress could finally pass it. The bill sets no emissions limits and does not change fuel-efficiency standards for cars. A proposal that $10 \%$ of US electricity should come from renewable sources by 2020 was also ditched.

In fact, energy efficiency and renewables take home just $\$ 5$ billion of the bill's $\$ 14.5$ billion in tax incentives, which are spread over ten years. The rest is largely a list of benefits for traditional energy industries, including a \$1.5-billion scheme for research and development into drilling for oil and gas in the Gulf of Mexico.

The bill may also pave the way for a resurgence of the nuclear industry in the United States, which has not signed off a new nuclear-plant construction since 1973. Energy companies interested in ending that streak can now count on a tax credit and reimbursement of any losses associated with unforeseen regulations, although it is not yet clear whether the industry will bite.

Science seems to do well out of the bill, with more than $\$ 30$ billion assigned to various research and development programmes over three years. But these are really just a starting point for negotiations by the appropriations committee, which is widely expected to be more frugal.

One clear change, however, is the creation of an undersecretary for science in the energy department, a position that many physical scientists hope will increase the clout of research in the department's budget wrangles. "This provides a voice at the table where the crucial decisions are made," says Michael Lubell, head of public affairs at the American Physical Society. Emma Marris

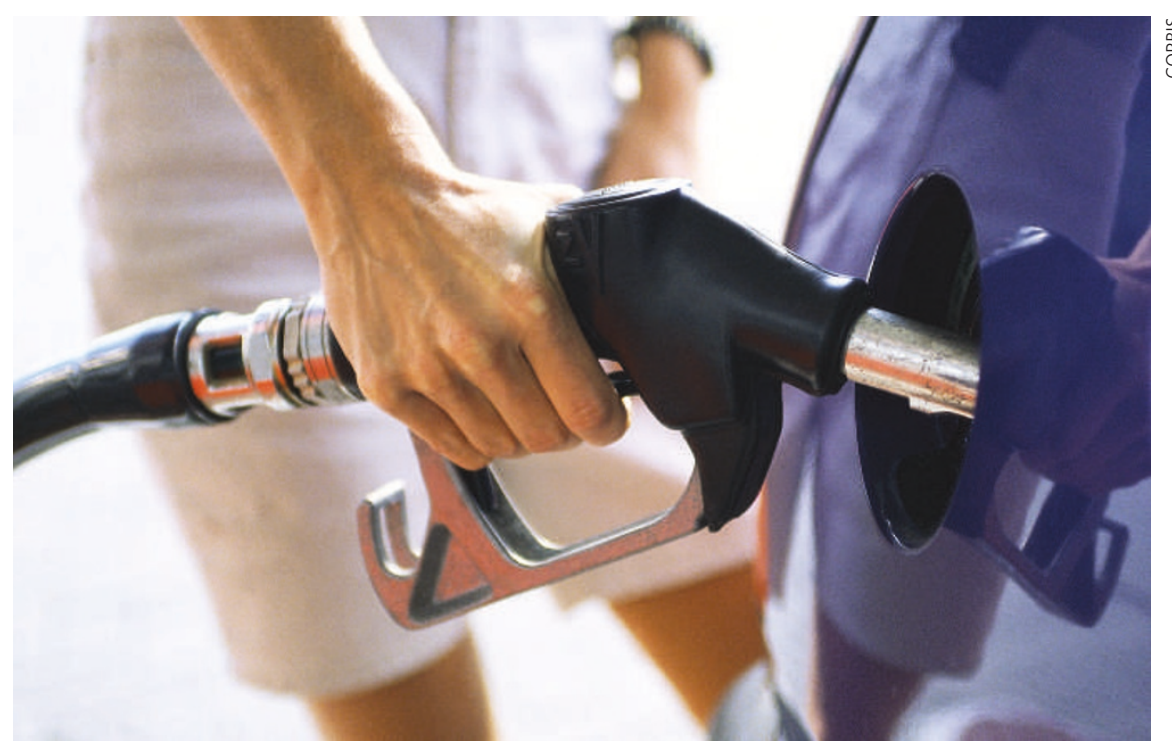

Guzzle on: the proposed US energy bill will not improve fuel efficiency in cars. 